\title{
LOCALISATION OF CYCLING EVENTS - CASE STUDY
}

\author{
[Lokalizace seriálů cykloeventů - př́ípadová studie] \\ Jiř́i Helešic ${ }^{1}$ \\ ${ }^{1}$ Slezská univerzita, Obchodně podnikatelská fakulta, Univerzitní nám. 1934/3,73340 Karviná \\ Email:helesic@opf.slu.cz
}

\begin{abstract}
Event tourism is perceived as a systematic planning and development of image-building factors and attractiveness of tourist destinations. Organizing sport events such as cycling race series on mountain bikes can be one of the instruments of destination management, or rather its components of event tourism. In our case, we chose the races with more than 15 years of tradition, "Bike for Life of Česká spořitelna" and "Author marathon tour". We analysed the spatial distribution of individual racing series in terms of their potential use for tourism and monitored attributes of tourism in municipalities with extended powers. The results show that the attractiveness of the landscape environment may be a deciding factor in decision of participation in bike events and tourism.
\end{abstract}

Keywords: landscape, regionalization, spatial distribution, sport events.

JEL classification: Z39

Doručeno redakci: 3.5.2016; Recenzováno: 19.5.2016; 19.5.2016; Schváleno k publikování: 30.11.2016

\section{Úvod}

Pořadatelství událostí a akcí sportovního charakteru můžeme zařadit do širší oblasti tak zvaného „EVENT TOURISM“. Event tourism je chápán jako součást snah budujících image atraktivit v destinacích. Jeho objektem zájmu jsou účastníci cestovního ruchu, kteří cestují, aby př́mo navštívili určitou událost, nebo kteří mohou být motivováni k návštěvě určité destinace z důvodu konání nějaké události (Getz 2008). Sportovní události a akce jsou specifické tím, že jsou jedinečné, dočasné, speciálně plánované, ř́zené a organizačně zabezpečené (Kotíková a Schwartzhoffová 2008). Kromě diváků mají také značné množství př́mých aktivních účastníků. To dělá ze sportovních akcí a událostí turistickou atrakci $\mathrm{s}$ možným dopadem na satelitní účet cestovního ruchu destinace potažmo státu (Ryglová, Burian a Vajčnerová 2011).

Výzkum vlivu konání sportovních eventů na ekonomické ukazatele pořadatele, či cestovní ruch destinace místa konání se zaměřuje na sportovní akce celosvětového významu tzv. „MEGA EVENTS“ nebo také „HALLMARK EVENTS“ (Roche 2000, Dowse, Hughes a Wong, in: Shipway 2012, Hall 1989, Ross 2006). Mezi „Hallmark sport events“ řadíme divácky nejsledovanější události typu Olympijských her, mistrovství světa v kopané, ragby, atletice apod. Efekty pořádání takovýchto sportovních událostí a akcí se projevují v nejrůznějších oblastech, mezi něž patří životní prostředí, ekonomika, sociokulturní sféra, pracovní trh, cestovní ruch atd. Z pohledu efektů konání sportovních akcí jsou zkoumány i některé akce nižší sportovní úrovně nebo sportovní události s menší diváckou sledovaností (např. Raabová 2012, Gibson et al. 2003, Gratton et al. 2006).

Cyklistické sportovně turistické akce mají, nejen v České republice, dlouholetou tradici a jsou nedílnou součástí turistiky. Považujeme je také za formu event turismu a tedy i za součást celého komplexu cestovního ruchu. V našem sdělení se zaměřujeme na analýzu lokalizace celorepublikových seriálů cyklistických závodů pro profesionály i amatérské jezdce na horských kolech. Jedná se o cyklistickou disciplínu s hromadným startem, využívající 
především nezpevněných cest ve zvlněném terénu. Dle užívaného typu kol umožňující jízdu v terénu se pro ně vžil název „Závody na horských kolech“ tedy „Mountain bike races“, dále jen MTB závody. Věnujeme se zde dvěma tradičním seriálům cyklistických závodů „Kolo pro život České spořitelny“ a „Author marathón tour“. Přesto, že se jedná o sportovně turistické akce značného rozsahu (cca 30 samostatných akcí během roku s celkově téměř 35000 aktivních účastníků), nejsou doposud z hlediska dopadu na cestovní ruch v České republice analyzovány.

Cílem pilotní studie je analýza vlivu lokalizace jednotlivých závodů na počty účastníků. Vycházíme ze sledování četnosti konání závodů v definovaných regionech, počtu jejich aktivních účastníků a z kvantifikace územního potenciálu vybraného místa pro cestovní ruch.

Předpokládáme, že lokalizace jednotlivých závodů je soustředěna na místa s vyšším potenciálem územních podmínek a předpokladů pro rozvoj cestovního ruchu. Předpokládáme dále, že místa konání s vyšším potenciálem využití pro cestovní ruch, potažmo jeho segmentu - cykloturistiku, přilákají také více účastníků. Pokusíme se také najít odpověd' na to, zda se vzdálenost místa konání od míst $\mathrm{s}$ největším potenciálem rezidentů (Praha a Brno) projeví i v počtu účastníků jednotlivých závodů.

Článek je standardně strukturován. Úvod je věnován event turismu a cyklistickým závodům. První kapitola se zabývá rajonizací České republiky z pohledu cestovního ruchu. Kapitola druhá pak blíže popisuje seriály sledovaných závodů, sběr a zpracování dat. Třetí kapitola je věnována výsledkům analýz a hledání kauzálních vztahů. Závěr shrnuje dosavadní zjištění a naznačuje možný směr dalšího výzkumu.

\section{Teoretická východiska}

Rajonizací území České republiky, z pohledu cestovního ruchu, se již od sedmdesátých let minulého století zabývají význační čeští a slovenští geografové. Turistickým a rekreačním využitím krajiny se zabývali např́íklad autoři jako Dohnal (1985), Šprincová $(1965,1990)$ Jesenicko, Novotná (2005) - Plzeňsko nebo Havrlant J. a M. (1986, 2005) - Ostravsko atd. Potenciál a předpoklady rozvoje cestovního ruchu České republiky obšírně také rozebírají, Vystoupil a Šauer (2011). V zásadě člení potenciál a předpoklady cestovního ruchu daného území na selektivní - ty ve své obecnosti nejsou předmětem našeho zájmu. Dále lokalizační se základním členěním na přírodní a kulturně - municipální a dále realizační s členěním na komunikační a materiálně technické. Jednotlivým atributům krajiny jsou přiřazovány bodové hodnoty a jejich procentuální váha.

Podrobněji se metodickým přístupům $\mathrm{k}$ hodnocení potenciálu cestovního ruchu území věnuje také Klapka (2008) a pokouší se modelově převést bodové vyjádření potenciálu (kulturně historického) do formy plošného vyjádření jako je tomu u vyjadřování př́írodního potenciálu kde se $\mathrm{v}$ nejjednodušší formě kvantifikace vzájemně poměřují plochy vhodné pro rekreaci s plochami méně vhodnými nebo nevhodnými. Prozatím však jsou takto modelově zpracovávány menší územní celky (Jihomoravský kraj, Plzeňsko, Vranov Nad Dyjí apod.). Jednotná kvantifikace potenciálu cestovního ruchu pro celou Českou republiku je zpracována Bínou (2010) a Vystoupilem (2006).

Bína (2010) ve své Aktualizaci potenciálu cestovního ruchu v České republice definuje, klasifikuje a přiřazuje bodové hodnoty jednotlivým skladebným prvkům potenciálu cestovního ruchu správních obvodů obcí s rozšířenou působností (ORP). Doplňuje tak své dřívější hodnocení potenciálu cestovního ruchu o vyjádření míry dostupnosti území individuální dopravou a obslužnosti území veřejnou dopravou. Do výpočtu aktualizovaného 
potenciálu cestovního ruchu území je také zahrnuto tzv. přiznání vyššího statutu území nebo jeho atraktivity. Jedná se např́ílad o záznam v seznamu kulturního dědictví UNESCO, přiznání statutu městské památkové rezervace, památkové zóny anebo začlenění území do „Národního parku“ (dále jen NP) či „Chráněné krajinné oblasti“ (dále jen CHKO). Vyšší stupeň ochrany turistických atraktivit mnohdy znamená omezení provozování některých aktivit. Řízené využití krajiny se statutem NP, CHKO může omezit škodlivé vlivy nadměrného využití pro turismus a na druhé straně může zatraktivnit lokalitu pro účastníky a zajisti tak pořadatelům odpovídající naplnění počtu startujících.

Kromě těchto dvou základních publikovaných přístupů k vymezení regionů v cestovním ruchu je v současnosti uplatňován moderní marketingový přístup, který vychází z premisy efektivního vytváření konkurence schopných produktů cestovního ruchu. Vytvářejí se tak územní celky, které se mohou svou atraktivitou (potenciálem) uplatnit na trhu cestovního ruchu. Tuto formu rajonizace České republiky uplatňuje při představování Č́ u nás i v zahraničí Česká centrála cestovního ruchu - „CzechTourism“. Na rozdíl od administrativního rozdělení na kraje a obce používá členění ČR na 17 turistických regionů rozdělených dále do 40 turistických oblastí. Tato regionalizace nerespektující administrativní členění ČR, potažmo v Evropské unii používanou „Nomenklaturu územních statistických jednotek“, přináší jisté obtíže v oblasti poskytování a sdílení informací a kooperace s orgány veřejné správy. Přesto, že se takto vzniklé destinace cestovního ruchu opírají primárně o regionalizaci dle atraktivity a uplatnění na trhu cestovního ruchu, nebyly doposud komplexně za Českou republiku kvantifikovány.

\section{Sběr dat a metodika zkoumání}

\subsection{Kolo pro život}

Seriál cyklistických závodů „Kolo pro život České spořitelny“ dále jen KPŽ ČS má již 16letou tradici. Každoročně se jej účastní na 25000 aktivních cyklistů. Postupně se od roku 2000 z jednotlivých MTB závodů pro profesionální cyklisty seriál rozrostl v celospolečenský fenomén, který láká celé rodiny amatérských cyklistů. V průběhu dubna až záŕí je každoročně realizováno cca 14 závodů rozdělených podle délky tratí na jednotlivé trasy. Většinou jde o „Hlavní závod“, zkrácená trasa „C“, fitness jízda „D“ a závody různých kategorií dětí dle věku. Profesionální cyklisté startují v kategorii „ELITE“, která čítá přibližně 50 - 100 jezdců, následně je závod vypsán pro muže a ženy v různých věkových kategoriích $(17-22,23-29$, 30-39, 40-49, 50-59, nad 60 let). Obdobně je tomu v rozdělení kategorií dětí a mládeže. Každého závodu se účastní 1500 - 1800 aktivních jezdců.

Pořadatelem celého seriálu závodů byla společnost ČS MTB Team s.r.o., jež se po vstupu hlavního investora od roku 2014 jmenuje Petr Čech Sport s.r.o. Společnost se specializuje na sportovní marketing a pořádání sportovních akcí. Vzhledem k úspěšnosti projektu KPŽ ČS jsou od roku 2011 pořádány obdobné seriály zimních běžeckých závodů „Stopa pro život“" a sjezdových MTB závodů „Enduro série“. Generálním partnerem je Česká spořitelna, hlavními partnery pak pojišt'ovna Kooperativa a Škoda auto, mediálními partnery Česká televize, Radiožurnál a cyklistické časopisy VELO atd. Společenský statut a vážnost dokladují institucionální partneři, jako je Ministerstvo školství, mládeže a tělovýchovy, Česká unie sportu a Asociace krajů České republiky.

\subsection{Author maraton tour}

Seriál cyklistických závodů „Author maraton tour“ dále jen AMT má 14letou tradici. Zahrnuje 10 závodů v průběhu dubna až září každého roku. Garantem pořadatelství je firma specializující se na výrobu a prodej kol značky AUTHOR a AGANG. Také zde jsou 
jednotlivé závody určeny profesionálním jezdcům a amatérům, rozděleným dle výkonnosti, genderové př́islušnosti a věkových kategorií obdobně jako je tomu u KPŽ ČS. Pořadatelé AMT se zaměřují i na doprovodné závody dětí a mládeže, závody rodinných teamů a firemních skupin. Celkově se závodů účastní na 12000 až 15000 závodníků ročně. Menší závody na Jižní Moravě mají průměrně okolo 300 závodníků. Stěžejní akce „AUTHOR KRÁL ŠUMAVY“ v okolí Klatov a „ČT AUTHOR CUP“ v Josefově Dole v Jizerských horách pak mají účast téměř desetinásobnou s bohatou mezinárodní účastí. Mediálními partnery jsou Česká televize (dř́ve televize NOVA) a cyklistické časopisy Cykloservis, Velo, Bike+Peloton. Hlavními partnery pak BMV Invent, Nuterend a Birel. Tratě jednotlivých závodů jsou opět rozděleny podle délky. Některé menší závody mají pouze jednu trat' okolo 50 km. Velké závody, jako je např́iklad „Author Šela Maraton“, pak i 3 tratě v rozsahu 26, 49 a $93 \mathrm{~km}$. Stejně tomu je v závodě „Král Šumavy“ se startem v Klatovech a tratěmi na 45, 70 a $105 \mathrm{~km}$ doplněnou o speciální trasu pro „handbike“ zdravotně postižených.

\subsection{Kvantifikace potenciálu území a počtu účastníků}

Celkově bylo sledováno na 210 závodů. Vzhledem k nejednotnému způsobu vedení evidence počtu účastníků závodů u jednotlivých pořadatelů jsme byli nuceni zkrátit společné sledované období na léta 2009 až 2015. V období let 1996 - 2009 vykazovalo vedení statistik počtu účastníků u jednotlivých pořadatelů zjevné nedostatky, a proto nebyly tyto údaje do našich analýz zahrnuty. Za ,počet účastníkư‘ je v našem př́ípadě považován oficiální záznam o počtu úspěšně absolvujících závodníků. V zájmu objektivity jsme nezapočítávali přihlášené závodníky diskvalifikované, nenastoupivší na trat', či ty, jež trat' neabsolvovali celou nebo v předepsaném časovém limitu. Podle našich zkušeností je to př́ibližně o 10 - $15 \%$ méně než je počet přihlášených účastníků. Dle oficiálních statistik tak v tomto období úspěšně absolvovalo některou z vybraných tratí na 207000 závodníků. Celkový objem potenciálních účastníků cestovního ruchu - pasivních i aktivních účastníků závodů určitě přesahuje čtvrt milionu. Údaje o seriálech cyklistických závodů jsme získávali z dostupných veřejných zdrojů organizátorů seriálu závodů „KPŽ ČS“ a „AMT“ a specialistů na sportovní časomíru „Sport Soft Timing“".

Místo konání stratu má bodovou charakteristiku výskytu, ale charakter distančního závodu na 30 až více než 100 kilometrů odpovídá metodice hodnocení př́rodního potenciálu území jako plošné charakteristiky. Za minimální jednotku plochy území místa konání jsme proto zvolili obce s rozšířenou působností (tzv. obce III. stupně, dále jen ORP).

Pro kvantifikaci předpokladů vyžití území (destinace) pro cestovní ruch byla využita aktualizovaná verze „Potenciálu cestovního ruchu v České republice“ od autorského kolektivu Ústavu územního rozvoje v Brně. Dle Bíny (2010) segmenty celkového potenciálu cestovního ruchu území tvoří ,potenciál atraktivit cestovního ruchu“ a „potenciál ploch a linií“ ovlivňujících cestovní ruch.

Atraktivitami cestovního ruchu jsou přírodní pozoruhodnosti jako osamělé skály a výchozy, jeskyně, skalní brány a podobně, ale také antropogenní díla jako např́klad zámky, hrady, kostely či celá historická centra. Tyto atraktivity mají vesměs „bodový“ výskyt a kvantifikována je jeho př́tomnost na území. Dále jsou tyto jednotlivé ,atraktivity“ diferencovány podle významových stupňů pro cestovní ruch. Významovou selekci atraktivit považuje Bína $(2001,2002,2010)$ pro cestovní ruch za nutnou.

Pro kvantitativní vyjádření ploch a linií ovlivňujících cestovní ruch bylo použito 7 primárních typů ploch a 6 typů linií. Každá z ploch a linií má určitý význam pro rozvoj cestovního ruchu. 
U ploch je orientace významu obousměrná. Tím je myšleno, že část ploch takto hodnocených má kladný vliv na rozvoj cestovního ruchu (Rekreační a turistická krajina typu II apod.) a část záporný (např. Průmyslový a těžební prostor). U linií (délka silniční sítě, délka břehů vodních ploch atd.) mají všechny typy podporující charakter. U každé plochy a linie je vyhodnoceno příslušné územní zastoupení z rozlohy vybraného území. Rámcové intervaly zastoupení ploch a linií zakládají intenzivní stupně podobně jako tomu je u významu atraktivit.

\subsection{Statistické zpracování dat}

Kromě základních deskripčních a komparativních metod jsme použili jednoduché statistické metody. Pro analýzu dat to byla metoda deskriptivní statistiky, pro ověření linearity a normality rozdělení dat jsme použili dvojrozměrnou projekci dat. Vzhledem $k$ tomu, že naše sledované proměnné počtu účastníků a lokalizace jednotlivých závodů mají limitovanou velikost výběrového souboru, rozhodli jsme se pro neparametrické metody měření míry asociace pomocí Kendallova koeficientu pořadové korelace (Hendl 2008). Dostupné údaje charakterizující cestovní ruch vybraného území jsme čerpali z databáze výzkumů a analýz agentury Czech Tourism, dále již zmíněného Ústavu územního rozvoje a veřejné databáze Českého statistického úřadu.

\section{Výsledky a diskuse}

V letech 2009 - 2015 úspěšně dokončilo některý ze závodů seriálu KPŽ ČS celkem 128700 aktivních účastníků a v seriálu AMT to bylo 78201 závodníků. Srovnáním výsledkových listin a evidence přihlášek odhadujeme, že se v uvedeném období cyklistických závodů pořádaných v rámci seriálů KPŽ ČS a AMT mohlo zúčastnit cca 235000 aktivních jezdců. Celkově bylo realizováno $\mathrm{v}$ tomto období 171 závodů. Vyšší průměrný počet účastníků má seriál závodů KPŽ ČS (1325) oproti 1160 v seriálu AMT. Počty účastníků jsou jedním z kritérií další spolupráce organizátorů a finančních a mediálních partnerů obou seriálů. Počty účastníků však nelze neustále navyšovat.

V prvé fázi výzkumu jsme analyzovali distribuci závodů a účastníků do jednotlivých krajů. Nejvíce závodů je lokalizováno ve Středočeském kraji. Jistou převahu zde mají pořadatelé KPŽ ČS (29) nad AMT (14). Dále je oběma pořadateli preferován kraj Liberecký, i když v opačném pořadí (KPŽ ČS 7, AMT 19).

Obrázek 1: Počty závodů a účastníků podle krajů (2009-2015)

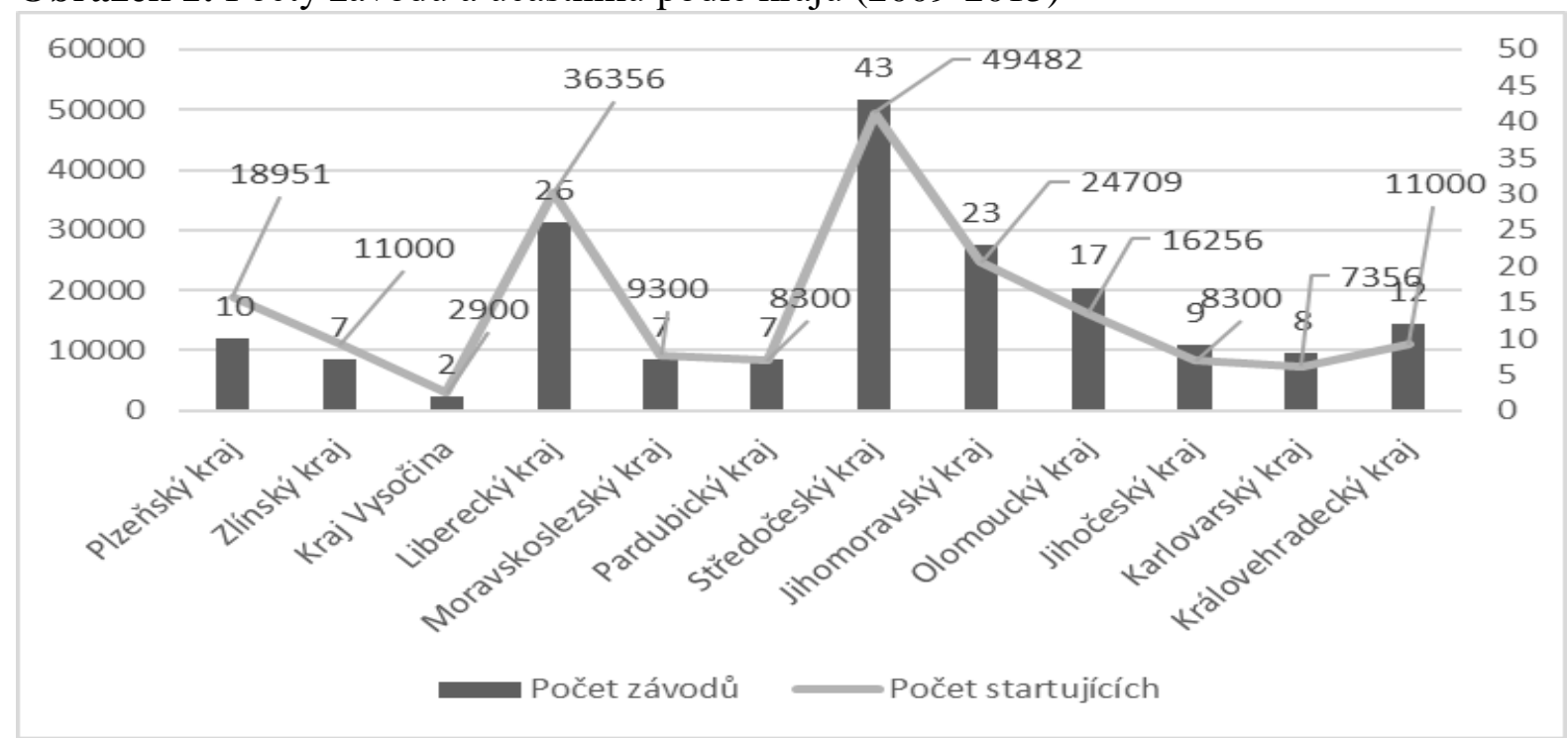

Zdroj: vlastní 
Organizátoři seriálu KPŽ ČS téměř polovinu závodů pořádají ve Středočeském a Královehradeckém kraji. Organizátoři AMT se soustřed'ují na Jihomoravský a Liberecký kraj. Lokalizace míst konání do jednotlivých krajů jistým způsobem odráží dopravní dostupnost pro organizační tým. Zatímco AMT má především lokální organizátory hlavní organizační tým KPŽ ČS vyjíždí ze sídla společnosti v Praze. Vlastní počet pořádaných sportovních událostí odráží zájmy, potřeby a strategie pořadatelů. Počty účastníků pak motivační složku a vnímání lokalizace z pohledu účastníkủ.

Nejvyšší průměrné počty účastníků jsme zaznamenali v kraji Plzeňském (1895) a Zlínském (1571). Naopak nejnižší průměrné počty účastníků zaznamenáváme v krajích Jihočeský, Karlovarský, Královehradecký. Ve všech případech je to těsně nad 900 účastníků na závod.

Ve výzkumu provedeném společností FOCUS Marketing \& Social Research pro agenturu CzechTourism v roce 2016 byly sledovány motivační atributy jednotlivých regionů ČR (krajů) pro trávení volného času a dovolených. V žádném z krajů není vnímána cykloturistika jako dominující motivační atribut. Nicméně v Plzeňském, Středočeském, Jihočeském kraji a kraji Vysočina patří cykloturistice pomyslné 5. místo v pořadí motivačních atributů. $\mathrm{Na}$ opačném konci spektra pak je překvapivě Zlínský kraj a Karlovarský, který si respondenti s cykloturistikou spojují jen velmi málo. Obdobně na tom je i Praha se zcela odlišnou motivační strukturou návštěvníků. Naše zjištění ukazuje tabulka č. 1. Návštěvníky vnímaná vhodnost kraje pro cykloturistiku nekoreluje s našimi výsledky účastnického zájmu o závody rozdělených dle krajů.

Tabulka 1: Počty závodů v kraji a motivační atributy k trávení volného času a dovolených

\begin{tabular}{|c|c|c|c|c|c|}
\hline Kraj & $\begin{array}{l}\text { Počet } \\
\text { závodů }\end{array}$ & $\begin{array}{l}\text { Počet } \\
\text { startujících }\end{array}$ & $\begin{array}{l}\text { Průměrný počet } \\
\text { startujících }\end{array}$ & $\begin{array}{l}\text { pořadí atributu } \\
\text { Cykloturistika }\end{array}$ & \% respondentů \\
\hline Plzeňský kraj & 10 & 18951 & 1895,1 & \begin{tabular}{|l}
5 \\
\end{tabular} & 26 \\
\hline Zlínský kraj & 7 & 11000 & 1571,4 & 12 & 11 \\
\hline Kraj Vysočina & 2 & 2900 & 1450,0 & 5 & 21 \\
\hline Liberecký kraj & 26 & 36356 & 1398,3 & 6 & 17 \\
\hline Moravskoslezský kraj & 7 & 9300 & 1328,6 & 10 & 17 \\
\hline Pardubický kraj & 7 & 8300 & 1185,7 & 6 & 18 \\
\hline Středočeský kraj & 43 & 49482 & 1150,7 & 5 & 19 \\
\hline Jihomoravský kraj & 23 & 24709 & 1074,3 & 7 & 23 \\
\hline Olomoucký kraj & 17 & 16256 & 956,2 & 9 & 14 \\
\hline Jihočeský kraj & 9 & 8300 & 922,2 & 5 & 26 \\
\hline Karlovarský kraj & 8 & 7356 & 919,5 & 12 & 8 \\
\hline Královehradecký kraj & 12 & 11000 & 916,7 & 6 & 22 \\
\hline Celkový součet & 171 & 203910 & 1192,5 & & \\
\hline
\end{tabular}

Na základě uvedených zjištění jsme se rozhodli dále analyzovat lokalizaci jednotlivých závodů. Při kvantifikaci atraktivnosti jednotlivých míst konání závodů jsme se rozhodli (jak uvedeno výše) pro Bínovo pojetí potenciálu cestovního ruchu území. Za nejmenší jednotku územního dělení jsme zvolili obce s rozšířenou působností. Kromě kvantitativního vyjádření celkového potenciálu jsme analyzovali i jeho jednotlivé segmenty. Porovnávali jsme př́slušnost území nebo jeho části k Chráněným krajinným oblastem nebo Národním parkům, kvantifikaci typu krajiny, hodnocení prírodních pozoruhodností s vlivem na cestovní ruch, dálniční a silniční dostupnost, vhodnost krajiny pro cykloturistiku. Tyto údaje jsme dále doplnili o dostupná data o cestovním ruchu jednotlivých ORP. Do našich analýz jsme zahrnuli atributy jako počty evidovaných hromadných ubytovacích zařízení v OPR, počet hostů v hromadných ubytovacích zařízeních, délka pobytů rezidentů a průměrná délka pobytu 
rezidentů v ORP. Vycházeli jsme z údajů Českého statistického úřadu za období 2012 - 2014 (2015 doposud nejsou k dispozici). Přehled sledovaných atributů nalezneme v tabulce „Místa konání závodů a jejich charakteristika“, která je př́lohou č. 1 tohoto textu. Celkem jsme analyzovali 8 atributů, které blíže vyjadřují hodnocení potenciálu území místa konání pro cestovní ruch. Jisté komunikační a realizační segmenty pak zastupují statistiky cestovního ruchu ze sběru dat Českého statistického úřadu a mapových podkladů.

Sledované cyklistické závody jednotlivých seriálů jsou představiteli sportovně turistických akcí v př́rodě. Sezónní výkyvy jsou jednou z charakteristik dat o cestovním ruchu. Proto jsme se také zaměřili na rozložení závodů během roku. Organizátoři seriálu KPŽ ČS se soustřed'ují na měsíce květen až záŕí. Během nich pořádají 3 závody měsíčně. Zatímco organizátoři AMT rozkládají pořadatelství závodů do delšího časového úseku (duben - ř́jen), a to pořádáním jednoho až dvou závodů měsíčně. $Z$ pohledu účastnického zájmu nalézáme také jisté rozdíly. (viz Tabulka 2)

Tabulka 2: Pořadatelství závodů a počty účastníků během roku

\begin{tabular}{|c|c|c|c|c|c|c|}
\hline \multirow{2}{*}{$\begin{array}{l}\text { seriál } \\
\text { měsíc }\end{array}$} & \multicolumn{3}{|c|}{$A M T$} & \multicolumn{3}{|c|}{ KPŽ ČS } \\
\hline & P_závodů & P_start & Průměr & P_závodů & P_start & Průměr \\
\hline duben & 7 & 7762 & 1109 & 1 & 900 & 900 \\
\hline květen & 14 & 12917 & 923 & 21 & 24200 & 1152 \\
\hline červen & 12 & 9247 & 771 & 20 & 19200 & 960 \\
\hline červenec & 7 & 9926 & 1418 & 21 & 27300 & 1300 \\
\hline srpen & 14 & 16874 & 1205 & 22 & 22200 & 1009 \\
\hline září & 2 & 516 & 258 & 22 & 30100 & 1368 \\
\hline ř́ijen & 7 & 20968 & 2995 & 1 & 1800 & 1800 \\
\hline
\end{tabular}

Zdroj: vlastní

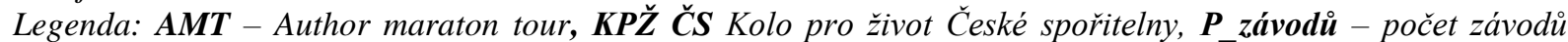
v letech 2009 - 2015 v jednotlivých měsicich, P_start - počet startujicích v letech 2009 - 2015 v jednotlivých mésícich

U KPŽ ČS je počet pořádaných závodů vyrovnaný. Celkový účastnický zájem a průměry počtu úspěšných účastníků se však již liší. První vrchol přichází v červenci a pak následuje záŕí. Nově je od roku 2014 zařazen říjnový finálový závod ve „Vysočina aréně“ v Novém Městě na Moravě se značnou účastnickou podporou. U seriálu AMT vidíme jeden z vrcholů $\mathrm{v}$ červenci a srpnu a druhý výrazný pak v říjnu. Jsou spojeny s tradičním pořádáním závodů v Jizerských horách - „ČT AUTHOR CUP“ a na Šumavě „AUTHOR KRÁL ŠUMAVY“. $\mathrm{Z}$ našich údajů nelze jednoznačně odvodit, že by účastnický zájem byl výrazně ovlivněn termínem konání jednotlivých závodů seriálu, ale je zřejmý př́iklon k účasti na říjnových „finálových“ závodech v Josefově Dole a ve „Vysočina aréně““.

I když se nabízí jednoduché konstatování, že organizátoři umist’ují pochopitelně jednotlivé závody do míst s vysokou atraktivitou, není to z našich dat zcela zřejmé. Předpokládali jsme, že počet účastníků jednotlivých závodů seriálu KPŽ ČS a AMT je ovlivněn potenciální atraktivitou daného území pro cestovní ruch. Dále jsme předpokládali, že účastníci závodů využívají i některé ze služeb cestovního ruchu v daném území a to se projeví ve sledovaných statistikách cestovního ruchu.

Pro ověření lineární závislosti mezi sledovanými proměnnými jsme použili dvojrozměrnou projekci dat. Zjistili jsme nelineární monotónní rozdělení dat, a proto jsme k měření síly statistické závislosti mezi sledovanými proměnnými použili neparametrickou sumarizační statistiku „Kendallovo tau“, tedy koeficient pořadové korelace. Sledovali jsme jak pozitivní anebo negativní vztah mezi proměnnými, tak jeho míru asociace. 
Za závisle proměnnou jsme považovali počty startujících na jednotlivých závodech seriálů. Vzhledem k tomu, že jsme zaznamenali jistou asymetrii ve vytíženosti jednotlivých krajů, doplnili jsme údaje o vzdálenost místa konání od Prahy a Brna. Předpokládali jsme, že dalším možným faktorem ovlivňujícím počty startujících je vzdálenost místa konání od Prahy či Brna, měst $\mathrm{s}$ největší koncentrací obyvatel a tedy i s nejvyšším účastnickým potenciálem. Průměrné dojezdové vzdálenosti jsou z Prahy 151 a z Brna 199 kilometrů.

Korelační koeficienty asociace průměrného počtu startujících na závodech seriálu KPŽ ČS, AMT a sledovaných charakteristik míst konání jednotlivých závodů ukazuje tabulka č. 3.

Tabulka 3: Kendallův koeficient asociace počtu účastníků a charakteristik ORP

\begin{tabular}{|c|c|c|c|c|c|c|c|}
\hline & & \multicolumn{2}{|l|}{ KPŽ Čs } & \multicolumn{2}{|l|}{ AMT } & \multicolumn{2}{|c|}{ Závody komplet } \\
\hline & & Kendall's tau_b & PStart & Kendall's tau_b & PStart & Kendall's tau_b & PStart \\
\hline \multirow{2}{*}{ Počet stratujících } & \multirow{2}{*}{ P.Start } & Correlation Coefficient & 1,000 & Correlation Coefficient & 1 & Correlation Coefficient & 1,000 \\
\hline & & $\mathrm{N}$ & 17 & $\mathrm{~N}$ & 10 & $N$ & 27 \\
\hline \multirow{2}{*}{ Body celkový potenciál } & \multirow{2}{*}{ B_CP } & Correlation Coefficient & ${ }^{*}-0,353$ & Correlation Coefficient & 0,111 & Correlation Coefficient & $-0,185$ \\
\hline & & Sig. (2-tailed) & 0,048 & Sig. (2-tailed) & 0,655 & Sig. (2-tailed) & 0,175 \\
\hline \multirow{2}{*}{ Body - potenciál ploch a linií } & \multirow{2}{*}{ B_PPL } & Correlation Coefficient & ${ }^{*}-0,559$ & Correlation Coefficient & $-0,422$ & Correlation Coefficient & $-0,043$ \\
\hline & & Sig. (2-tailed) & 0,002 & Sig. (2-tailed) & 0,089 & Sig. (2-tailed) & 0,755 \\
\hline \multirow{2}{*}{ Body-potenciál atraktivi CR } & \multirow{2}{*}{ B_PA } & Correlation Coefficient & $-0,221$ & Correlation Coefficient & 0,244 & Correlation Coefficient & $-0,197$ \\
\hline & & Sig. (2-tailed) & 0,217 & Sig. (2-tailed) & 0,325 & Sig. (2-tailed) & 0,150 \\
\hline \multirow{2}{*}{$\begin{array}{r}\text { Body -potenciál ploch Chráněných } \\
\text { krajinných oblastí a Národních parkủ ORP }\end{array}$} & \multirow{2}{*}{ B_CHKO/NP } & Correlation Coefficient & $-0,147$ & Correlation Coefficient & $-0,378$ & Correlation Coefficient & 0,031 \\
\hline & & Sig. (2-tailed) & 0,410 & Sig. (2-tailed) & 0,128 & Sig. (2-tailed) & 0,819 \\
\hline \multirow{2}{*}{ Body-typ krajiny } & \multirow{2}{*}{ B_TYP } & Correlation Coefficient & $* *-0,471$ & Correlation Coefficient & ${ }^{*} 0,511$ & Correlation Coefficient & 0,088 \\
\hline & & Sig. (2-tailed) & 0,008 & Sig. (2-tailed) & 0,040 & Sig. (2-tailed) & 0,518 \\
\hline \multirow{2}{*}{ Body-přírodní potenciál } & \multirow{2}{*}{ B_PP } & Correlation Coefficient & $-0,052$ & Correlation Coefficient & 0,182 & Correlation Coefficient & $-0,043$ \\
\hline & & Sig. (2-tailed) & 0,773 & Sig. (2-tailed) & 0,261 & Sig. (2-tailed) & 0,755 \\
\hline \multirow{2}{*}{ Body-dálniční dostupnost } & \multirow{2}{*}{ B-DD } & Correlation Coefficient & 0,265 & Correlation Coefficient & $-0,022$ & Correlation Coefficient & 0,168 \\
\hline & & Sig. (2-tailed) & 0,138 & Sig. (2-tailed) & 0,929 & Sig. (2-tailed) & 0,219 \\
\hline \multirow{2}{*}{$\begin{array}{r}\text { Počet hostů v hromadných ubytovacích } \\
\text { zařizeních - rezidenti }\end{array}$} & \multirow{2}{*}{ P_host $/ r$} & Correlation Coefficient & $-0,294$ & Correlation Coefficient & 0,289 & Correlation Coefficient & $-0,197$ \\
\hline & & Sig. (2-tailed) & 0,099 & Sig. (2-tailed) & 0,245 & Sig. (2-tailed) & 0,150 \\
\hline \multirow{2}{*}{ Počet nocí v HUZ - rezidenti } & \multirow{2}{*}{ P_noc/r } & Correlation Coefficient & $-0,103$ & Correlation Coefficient & 0,067 & Correlation Coefficient & $-0,088$ \\
\hline & & Sig. (2-tailed) & 0,564 & Sig. (2-tailed) & 0,788 & Sig. (2-tailed) & 0,518 \\
\hline \multirow{2}{*}{ Průměrná délka pobytu - rezidenti } & \multirow{2}{*}{ P-DP } & Correlation Coefficient & ${ }^{*}-0,426$ & Correlation Coefficient & $-0,422$ & Correlation Coefficient & $-0,071$ \\
\hline & & Sig. (2-tailed) & 0,017 & Sig. (2-tailed) & 0,089 & Sig. (2-tailed) & 0,602 \\
\hline \multirow{2}{*}{$\begin{array}{r}\text { Počet hromadných ubytovacích zařizení v } \\
\text { ORP }\end{array}$} & \multirow{2}{*}{ P_HUZ } & Correlation Coefficient & $-0,118$ & Correlation Coefficient & $-0,022$ & Correlation Coefficient & $-0,009$ \\
\hline & & Sig. (2-tailed) & 0,510 & Sig. (2-tailed) & 0,929 & Sig. (2-tailed) & 0,950 \\
\hline \multirow{2}{*}{ Počet lůžek v HUZ } & P PI & Correlation Coefficient & $-0,176$ & Correlation Coefficient & 0,156 & Correlation Coefficient & $-0,111$ \\
\hline & P_PL & Sig. (2-tailed) & 0,323 & Sig. (2-tailed) & 0,531 & Sig. (2-tailed) & 0,416 \\
\hline & & Correlation Coefficient & $-0,005$ & Correlation Coefficient & $-0,067$ & Correlation Coefficient & 0,009 \\
\hline Vzdálenost mista konání od Prahy & Km Praha & Sig. (2-tailed) & 0,874 & Sig. (2-tailed) & 0,788 & Sig. (2-tailed) & 0,950 \\
\hline & & Correlation Coefficient & ${ }^{*} 0,441$ & Correlation Coefficient & 0,333 & Correlation Coefficient & 0,100 \\
\hline Vzdálenost místa konání od Brna & KM Brno & Sig. (2-tailed) & 0,013 & Sig. (2-tailed) & 0,180 & Sig. (2-tailed) & 0,466 \\
\hline$y$ & Vhodn. & Correlation Coefficient & ${ }^{* *}-0,5$ & Correlation Coefficient & $-0,289$ & Correlation Coefficient & $-0,413$ \\
\hline & Vhoan. & Sig. (2-tailed) & 0,005 & Sig. (2-tailed) & 0,245 & Sig. (2-tailed) & 0,227 \\
\hline
\end{tabular}

Zdroj: vlastní

V seriálu závodů „Kolo pro život České spořitelny“ můžeme na zvolené statistické hladině významnosti $(\alpha \leq 0,05)$ zamítnout nulovou hypotézu H0: $\tau=0$, že mezi proměnnými není asociace, u těchto sledovaných ukazatelů: Celkový potenciál území pro cestovní ruch, Potenciál ploch a linií, Typ krajiny, Průměrná délka pobytu hostů z ČR, Vzdálenost místa konání od Brna a Vhodnost krajiny pro cykloturistiku. U závodů seriálu „Author maraton tour" můžeme totéž konstatovat pouze u vztahu počtu startujících a Typu krajiny.

Jak jsme již uvedli výše, předpokládali jsme, že lokalizace závodů do míst s vyšší atraktivitou a prírodním potenciálem pro cestovní ruch přilákají i více účastníků. V této souvislosti musíme poznamenat, že naše údaje o počtu účastníků vycházejí ze sedmiletého sledování a proto průměrné počty účastníků na závodě považujeme za stabilní vyjádření účastnické podpory seriálu i lokalizace jednotlivých závodů.

Zjistili jsme statisticky významné asociace mezi počtem účastníků a celkovým potenciálem atraktivit území pro cestovní ruch a některými jeho segmenty. K našemu překvapení však u 
seriálu závodů KPŽ ČS měly tyto vztahy negativní monotónní závislost. U Celkového potenciálu atraktivit cestovního ruchu na hladině významnosti $\alpha \leq 0,05$, u Potenciálu ploch a linií a kvantifikace Typu krajiny pak na hladině významnosti $\alpha \leq 0,01$. Tato místa negativně asociují s délkou pobytu českých účastníků cestovního ruchu v ORP. Naše analýzy ukazují, že organizátoři seriálů lokalizují své závody i do míst s nižším potenciálem atraktivit pro cestovní ruch a také jeho segmenty orientované na přírodní atraktivity. I přes toto rozhodnutí organizátorů seriálu KPŽ ČS je zájem účastníků vyšší než u seriálu AMT a ještě se výrazně neváže na atraktivitu prostředí.

Počty účastníků v obou seriálech asociují, i když v opačném směru s kvantifikací atraktivity typu krajiny, kde se závod koná. U závodů seriálu KPŽ ČS je nejčastěji využívaná „Krajina typu II“: „členitá vrchovinná krajina s lesy, loukami a pastvinami, s četnými vyhlídkovými body, s relativně drobným osídlením; nebo krajina s plochým reliéfem, ale s vysokou estetikou danou střídáním lesů, luk a rybniki̊, velmi vhodná pro cykloturistiku; nebo krajina monumentálních izolovaných sopečných vrchů s vysoce kvalitními rozhledovými misty; nebo krasová krajina s méně vyvinutými povrchovými tvary" s obecně podporujícím vlivem na cestovní ruch, u seriálu AMT je více využívána krajina typu I: „horská a vyšši podhorská krajina s vysokým podílem lesù, s malebnou členitostí reliéfu predstavujici kvalitní prostředí pro letni $i$ zimní turistiku, rekreaci a zimní sporty, $s$ drobným poprrípadě rozptýleným osídlením nebo krasová krajina s vyvinutými povrchovými tvary, zejména skalnatými kaňony; nebo krajina s vysokou hustotou výrazných skalních útvarü“ s výrazně podporujícím vlivem na cestovní ruch. U seriálu AMT však nalézáme také vyšší zastoupení „urbanizovaného prostoru“: „, souvislé převažujicí plochy intravilánu širící se z jádrového mésta (nad zhruba 20000 obyvatel) do okolních obci" s omezujícím obecným vlivem na cestovní ruch (Bína 2001). Na základě našich zjištění musíme konstatovat, že očekávanou pozitivní vazbu mezi počtem účastníků a atraktivitou prostředí pro cestovní ruch se nám nepodařilo prokázat. U seriálu AMT jsme zaznamenali pozitivní asociaci mezi počtem účastníků a potenciálem Typu krajiny avšak dále s žádným dalším segmentem prŕírodních atraktivit.

Pořadatelé seriálu AMT deklarují na svém portálu svou marketingovou strategii: „Domáci seriál maratonů Author maraton Tour je v mnoha ohledech výjimečný. Už to, že v roce 2016 odstartuje 14. ročník mluví samo za sebe. Ale to hlavní, o co zde od samého začátku jde, je predevším spokojený závodnik, připadně divák. Jinými slovy - celá Author Maraton Tour je zde pro lidi, kteři horskými koly žijí. Právě jim má nabídnout nejen různorodou náročnost tratí, ale i jejich začlenění do skutečně krásné krajiny. Přestože jde mnoha jezdcưm logicky primárně o samotný výkon, pořadatelé se již řadu let všemi silami snaží, aby lokality, v nichž se jednotlivé závody konají, prrinesly mnohem více zážitkì, než jen fyzické vypětí a konkrétní druh terénu "I. Dle našich analýz při lokalizaci svých závodů opravdu využívají obce s rozšířenou působností, které mají vyšší průměrné ukazatele celkového potenciálu využití krajiny pro cestovní ruch. Přesto se nám statisticky významný pozitivní asociační vztah projevil pouze u potenciálu Typu krajiny.

Účastníci seriálu závodů KPŽ ČS se při svém rozhodování o účasti na závodech primárně neorientují na atraktivitu místa konání a ani na hodnocení jeho vhodnosti pro cykloturistiku. $\mathrm{Z}$ našich dat je zřejmé, že se dlouhodobě a v hojném počtu účastní i závodů v místech jako jsou Odry a Oderské vrchy, Holešov a Hostýnské vrchy, Mladá Boleslav, Hustopeče a podobně, tedy $\mathrm{v}$ místech $\mathrm{s}$ nižším celkovým potenciálem pro cestovní ruch i nižším ohodnocením jeho především přírodních segmentů nebo vhodnosti pro cykloturistiku.

\footnotetext{
${ }^{1}$ [online] [vid. 25.dubna 2016] Dostupné z: http://cz.author.eu/author-maraton-tour
} 
Negativní asociační vztah mezi počty účastníků a ukazatelem délky pobytu občanů ČR v obci s rozšířenou působností kde se závod pořádá, si logicky spojujeme s tím, že místa s nižší atraktivitou pro cestovní ruch mají i nižší návštěvnost a také kratší délku pobytu (Palatková 2006).

Pozitivní monotónní závislost $(\alpha<0,05)$ zjištěná u vztahu počtu startujících v závodech KPŽ ČS a vzdáleností místa startu od města Brna naznačuje, že účastnický potenciál stoupá se vzdáleností místa startu od Brna. Domníváme se, že vysvětlením by mohlo být zjištění, že převážná část závodů seriálu KPŽ ČS je situována do Středočeského a Královehradeckého kraje. Tyto kraje jsou blíže nepochybně vyššímu místu účastnického potenciálu cyklistů z Prahy. Dále zde hraje svou roli i dálniční spojení Praha - Brno. Vysvětlením by mohlo být také to, že ve směru Brno - Praha se k místu startu sčítají proudy účastníků z různých míst a ten z Brna a okolí je ochoten cestovat i dále. V opačném směru je možný úbytek účastníků z Prahy se zvětšující se vzdáleností ve směru na Brno a dále. Nicméně koeficientem determinace tohoto vztahu $\left(\tau^{2} * 100=19,4\right)$ lze vysvětlit pouze cca $20 \%$ variability počtu účastníků závodů KPŽ ČS. Hodnocení dálniční dostupnosti míst startu výrazně neasociuje s počtem účastníků a proto nemůžeme zamítnout $\mathrm{H}_{0}$ a konstatujeme, že ačkoliv je dominantní formou dopravy účastníků na místo startu doprava automobilová, nemá její kvalita, vyjádřená dálniční dostupností ORP, výrazný vliv na počty účastníků.

Kvantitativní vyjádření Potenciálu ploch a linií je založeno na součtu hodnocení typu krajiny a dále na hodnocení dálniční a silniční dostupnosti, délce a typu železničních tratí, délce břehů vodních ploch, délce řek v hodných ke splouvání a zastoupení ploch národních parků a chráněných krajinných oblastí. Počty účastníků seriálu KPŽ ČS výrazně asociuje s nižší hodnotou tohoto ukazatele $\mathrm{v}$ obcích $\mathrm{s}$ rozšířenou působností, kde je trat' závodu situována. Jak je výše uvedeno, zdá se, že dálniční dostupnost není limitujícím faktorem pro vysoký účastnický zájem a tak i lokalizace s nižším potenciálem ploch a linií významně neovlivní počty účastníků.

Očekávali jsme, že lokalizace závodů do míst s přidanou hodnotou institucionální ochrany př́rody (národní parky a chráněné krajinné oblasti) bude mít vliv i na počty závodníků. Nicméně zjištěná míra sociace je v obou př́ipadech nízká. Vysvětlujeme si to jistými omezeními pro chování organizátorů i účastníků v těchto lokalitách.

Hodnocení vhodnosti území pro cykloturistiku v sobě zahrnuje jak př́rodní atributy, tak i služby či podmínky. Bína (2002, s. 6,7) uvádí, že „Ve stupni 1 je rovinatá až pahorkatinná krajina $\mathrm{v}$ zemědělských územích $\mathrm{v}$ oblastech bez výraznějšího ekologického poškození, $\mathrm{s}$ malým podílem lesů a kompaktními sídly, s vhodnými vedlejšími silnicemi a polními cestami. Stupeň 2 tvoří rovinatá až pahorkatinná krajina v oblastech, kde je více lesů a vodotečí, popř. i vodních ploch. Začleňovány jsou rovněž výše položené krajiny odpovídající vrchovinám, které mají charakter rozevřených údolí a širokých hřbetů. Do stupně 3 řadíme území s větším podílem lesů, nízkou hustotou osídlení a vysokou krajinnou estetikou, často i náhorní plošiny hor.“ Jak bylo uvedeno výše, pro konání závodů je především využívána krajina Typu I a II. Tedy horská, podhorská a vrchovinná krajina. Nelze tedy očekávat nějakou vyšší asociaci mezi hodnocením vhodnosti krajiny pro cykloturistiku veřejnosti a počtem účastníků cyklistických závodů.

Statistické ukazatele o cestovním ruchu v obcích s rozššřenou působností, publikované Českým statistickým úřadem, nejsou př́liš rozsáhlé. Ukazatele o počtu hromadných ubytovacích zařízení a počtu lůžek v nich jsou relativně stabilní a tak jsme ani neočekávali, že 
by počty účastníků mohli jejich hodnotu ovlivnit. Počty účastníků závodů seriálu KPŽ ČS asociují s místy s kratší délkou pobytu v ORP. Vysvětlením je i asociace tohoto ukazatele s nižší atraktivitou území pro cestovní ruch. Oba seriály závodů mají celorepublikovou působnost a čerpají především $\mathrm{z}$ domácích účastníků tedy rezidentů $\mathrm{z}$ pohledu cestovního ruchu. V současném stavu našeho výzkum v této oblasti nelze prozatím konstatovat, že účastníci cykloeventů ovlivňují tyto sledované ukazatele o cestovním ruchu. Proto se v dalším období pokusíme zaměřit na skladbu účastníků, odkud pochází a zda a jak využívají služeb cestovního ruchu při účasti na závodech seriálů KPŽ ČS a AMT.

Ne zanedbatelnou skutečností je zjištění, že pořadatelé seriálu KPŽ ČS obměňují lokality svých závodů a hledají optimální kombinaci lokalizačních předpokladů pro maximalizaci účastnického potenciálu. U seriálu AMT je patrná snaha o stabilní a tradiční lokalizaci s využitím atraktivity prostředí.

Přes rozdílnost př́stupů $\mathrm{k}$ lokalizaci jednotlivých závodů představují oba seriály závodů, především svou dlouholetou tradicí a počtem účastníků, značný turistický potenciál využitelný v cestovním ruchu.

\section{Závěr}

Využití krajiny je mnohovýznamovým pojmem. Setkáváme se s ním v geografii, ekonomických vědách i cestovním ruchu. Vlastní využití krajiny pro cestovní ruch bývá spojováno s jejími předpoklady pro toto využití. Použili jsme rozdělení předpokladů na „lokalizační“ a „realizační“ dle Bíny (2010), jimiž je vyjádřen potenciál využití definovaných regionů, v našem př́ípadě obcí $\mathrm{s}$ rozšířenou působností, pro cestovní ruch. Ve shodě s citovaným autorem musíme zdůraznit, že žádný formalizovaný model nemůže postihnout lokalizační podmínky ve zvolených regionech v jejich naprosté úplnosti.

Dochází také ke změnám vnímání vhodnosti krajiny pro určité aktivity spolu se změnou její vybavenosti (transportní zařízení a budování specifické infrastruktury, použité prostředky elektricky asistovaná kola apod.). V průběhu času se tvoří a také bohužel i zanikají tradice pořádání eventů nejrůznějšího charakteru s vlivem na návštěvnost daného území. Stejně tak se mění v čase i předpoklady realizační. Některé v horizontu měsíců, let i celých desetiletí (např́íklad budování dálniční sítě).

V našem článku se pokoušíme analyzovat prostorovou distribuci seriálu závodů na horských kolech pro profesionály i amatérské jezdce. Tyto závody mají dlouholetou tradici a nezpochybnitelnou sportovní úroveň. Stali se událostmi - „EVENTS“, které do určité oblasti přivádějí aktivní účastníky, ale i diváky. Vzhledem $\mathrm{k}$ tomu, že se jedná o aktivitu konanou převážně mimo domov, lze tyto profesionální a amatérské závodníky považovat za jistým způsobem specifické účastníky cestovního ruchu.

Naše výsledky asociační analýzy naznačují, že strategie pořadatelů AMT, kteří se z hlediska lokalizace závodu zaměřují na místa $\mathrm{s}$ vyšším potenciálem využití krajiny pro cestovní ruch, jsou v souladu s očekávaným vyšším počtem účastníků. Pořadatelům seriálu KPŽ ČS, kteří se snaží přivést sportovní události i do míst s nižším celkovým potenciálem využití krajiny pro cestovní ruch se daří navyšovat celkové počty účastníků. Negativní monotónní závislost mezi počtem účastníků a délkou pobytu $\mathrm{v}$ hromadných ubytovacích zařízeních vztahujeme ke skutečnosti, že méně atraktivní turistická místa jsou méně a kratší dobu navštěvována. Nabízí se otázka, zda tyto charakteristiky cestovního ruchu v obcích s rozšířenou působností mohou 
být ovlivněny právě realizací cykloeventů, či rozhodnutím účastníků navštívit danou oblast z důvodu aktivní či pasivní účasti na závodu nebo príípravou na něj.

Domníváme se ve shodě s autory výzkumů o dopadu pořádání sportovních událostí na cestovní ruch např. Raabová (2012), Gratton, Shibli a Coleman (2006), Shipway a Fyall, (2012), že vhodně zvolenou strategií využití krajiny a jejího potenciálu pro pořádání událostí a akcí (EVENTS) lze ovlivnit cestovní ruch dané lokality. Organizace sportovních i kulturních eventů se může stát produktem i nástrojem destinačního managementu s cílem valorizace potenciálního využití destinace a může přispět ke zvýšení konkurenceschopnosti daného regionu na trhu cestovního ruchu.

Jsme si vědomi, že události a akce mají relativně krátkou dobu trvání, a i proto lze jejich př́mý vliv na cestovní ruch hůře zaznamenat. Nicméně seriály závodů mají letitou tradici, a proto předpokládáme, že účastníci závodů tato místa navštěvují opakovaně anebo sem jezdí i v souvislosti s jinou aktivitou, než je cyklistika. Multiplikační efekt pořadatelství eventů a jejich dopad na cestovní ruch tak leze s jistou pravděpodobností předpokládat, ale prozatím nikoliv prokázat. Proto se $\mathrm{v}$ dalším období zaměříme na výzkum této problematiky.

\section{Literatura}

[1] BÍNA, J., 2010. Aktualizace potenciálu cestovního ruchu v České republice. Závěrečná zpráva úkolu B.10/CR [online]. [vid. 12. duben 2016]. Dostupné z: http://www.uur.cz/images/uzemnirozvoj/cestovniruch/potencialCR/PotencialCR-text.pdf

[2] BÍNA, J., 2002. Hodnocení potenciálu cestovního ruchu v obcích České republiky. Urbanismus a územní rozvoj, roč. V, č. - 1/2002 [online]. [vid. 12. duben 2016].

Dostupné z: https://is.muni.cz/el/1456/jaro2007/KRGCR/um/Hodnocen_potenci_lu_CR_v_obc_ch_ _R_b_na.pdf

[3] DOHNAL, V. et al., 1985. Rajonizace cestovního ruchu ČSR. Praha: Merkur, 167 s.

[4] GETZ, D., 2008. Event tourism: Definition, evolution and Research. Tourism Management 29, s. 403 - 428 [online]. [vid. 19. duben 2016] Dostupné z: www.science.direct.com

[5] GIBSON, H. J., C. WILLMING and A. HOLDNAK, 2003. Small-scale event sport tourism: fans as tourist. Tourism Management 24, s. 181-190. [online]. [vid. 19. duben 2016] Dostupné z: $\underline{\text { www.science.direct.com }}$

[6] GIORGIO, A. and G. SPINELLI, 2009. Sport tourism role in IRT theory. A conceptrula frame work, In: 3rd IRT International Scientific Conference. Helwan Egypt.

[7] GIBSON, H., 2013. Sport tourism: concepts and theories. New York, London: Routledge. ISBN: 0415348099

[8] GRATTON, CH., S. SHIBLI and R. COLEMAN, 2006. The economic impact of major sports events: a review of events in the UK. The Sociological Review, Wiley Online

Library [online] [vid. 27. záŕí 2016]. Dostupné z:

http://onlinelibrary.wiley.com/doi/10.1111/j.1467-954X.2006.00652.x/abstract

[9] HALL, C. M., 1989. The definition and analysis of hallmark tourist events. GeoJournal, 19(3), 263-268. 
[10] HAVRLANT, J., 2005. Vývoj rekreačních forem cestovního ruchu v oblasti Beskyd. In: M. FŇUKAL a P. PTÁČEK, Geografie, cestovní ruch a rekreace. Olomouc: Univerzita Palackého v Olomouci, s. 133-148. ISBN 80-2441-221-7

[11] HAVRLANT, M., 1986. Rekreačni potenciál a zařizeni terciární sféry v Ostravské průmyslové oblasti. Ostrava: Ostravská univerzita. ISBN 80-7042-044-8

[12] HENDL, J., 2008. Kvalitativní výzkum: základní teorie, metody a aplikace. 2. vyd. Praha: Portál, 408 s. ISBN 978-80-7367-485-4.

[13] KIRÁĹOVÁ, A., 2003. Marketing destinace cestovního ruchu. Praha: Ekopress, 173 s. ISBN 80-86119-56-4.

[14] KLAPKA, P., E. NOVÁKOVÁ a B. FRANTÁL, 2008. Metodologické př́stupy k hodnocení potenciálu cestovního ruchu území. Miscellanea Geographica, 2008(14), 65-70. ISSN 2084-6118

[15] KOTÍKOVÁ, H. a E. SCHWARTZHOFOVÁ, 2008. Nové trendy v poŕádání akcí a událostí (events) v cestovním ruchu. Praha: MMR ČR, 99 s. ISBN 978-80-87147-05-4.

[16] NOVOTNÁ, M., 2005. Ohodnocení geografického potenciálu pro cestovní ruch v Plzeňském kraji. In: Acta Facultatis Rerum Naturalium Universitatis Comenianae, Geographica, No. 3, 392-405. Bratislava: Univerzita Komenského, ISBN 80-223-2144-3.

[17] PALATKOVÁ, M., Š. TITTELBACHOV a T. VALSKÁ, 2012. Marketingová koncepce cestovního ruchu 2013-2020 [online]. [vid. 24. dubna 2016]. CZECHIT - interní studie. Dostupné z: $\quad$ http://www.czechtourism.cz/getmedia/fa20d069-2d8b-4d19-8591b19083531b33/11_12_13_marketingova_strategie.pdf.aspx

[18] PALATKOVÁ, M., 2006. Destinační management a vytváření produktů v cestovním ruchu. Prolínání destinací a destinační partnerství. Hospodářská komora hlavního města Prahy. [online], [vid. 12. května 2016], Dostupné z: http://www.mmr.cz/getmedia/ 3869c784-9a21-41d7-aa4e-3ae736eccbe4/GetFile7_3.pdf

[19] RAABOVÁ, T. a kol., 2012. Ekonomický dopad mezinárodních běžeckých závodi̊ RunCzech.com 2011. Praha: EconomicimpacT v.o.s

[20] ROCHE, M., 2000. Mega-events and modernity: Olympics and expos in the growth of global culture. London: Routledge. ISBN 0761955603

[21] ROSS, S. D., 2001. Developing sports tourism An eGuide for Destination Markets and Sport Events Planners. National Laboratory for Tourism and eComerce, University of Illinois [online] [vid. 12. května 2016 ]. Dostupné z: http://www.lib.teiher.gr/ webnotes/sdo/Sport\%20Tourism/Sport-Tourism\%20Development\%20Guide.pdf

[22] RYGLOVÁ, K., M. BURIAN, I. VAJČNEROVÁ et al., 2011. Cestovní ruch podnikatelské principy a príležitosti v praxi. Praha: Grada Publishing, a.s. ISBN 978-80247-4039-3

[23] SHIPWAY, R. and A. FYALL, 2012. International Sports Events - Impact, experience and identities. New York, London: Routledge. ISBN 80-978-0-203-13123-7.

[24] ŠPRINCOVÁ, S. a I. LEPKA, 1990. Rajonizace oblasti cestovního ruchu Jeseníky (srovnávací studie). In Acta Universitatis Palackianae Olomucensis. Facult as Rerum Naturalium 98, Geographica-Geologica XXIX, 89- 106. Olomouc: Univerzita Palackého v Olomouci, 
[25] ŠPRINCOVÁ, S., 1965. The Regionalization of Tourism. In: Edice referátů k zasedání Komise pro ekonomickou rajonizaci při Mezinárodní geografické unii Komunikát: 4. Brno: GGÚ ČSAV, 6 s.

[26] VYSTOUPIL, J. a kol., 2006. Atlas cestovniho ruchu České republiky. Praha: MMR, ISBN 80-220-7256-1.

[27] VYSTOUPIL, J., M. ŠAUER a kol., 2011. Geografie cestovního ruchu České republiky. Plzeň: nak1. Aleš Čeněk s.r.o., 315 s. ISBN 978-80-7380-340-7 315.

[28] Destinační management ČR 2016. Závěrečná zpráva z marketingového výzkumu, [online].[vid. 20. záŕí 2016 ]. Brno: FOCUS Marketing \& Social Research. Dostupné z: http://www.czechtourism.cz/institut-turismu/marketingovy-vyzkum/analyzy/turistickypotencial-kraju-cr/ 


\section{Př́loha 1}

Místa konání závodů a jejich charakteristiky

\begin{tabular}{|c|c|c|c|c|c|c|c|c|c|c|c|c|c|c|c|c|c|c|c|c|}
\hline Seriál & Název závodu & Místo startu & Měsíc & ORP & P.Start & B_CP & B_PPL & B_PA & $\begin{array}{c}\text { B_CHKO } \\
\text { /NP }\end{array}$ & B_TYP & B_PP & $B-D D$ & P_host $/ r$ & P_noc/r & $P-D P$ & P_HUZ & P_PL & Km Praha & Km Brno & $\begin{array}{c}\text { Vhodn. } \\
\text { cyklo }\end{array}$ \\
\hline AMT & AUTHOR VALTICKÉ CYKLOBRANÍ & Valtice & ZÁŘí & Břeclav & 258 & 1150 & 280 & 870 & 0 & -80 & 0 & 150 & 112755 & 212115 & 1,9 & 108 & 5094 & 258 & 59 & 32 \\
\hline AMT & LAHOFER AUTHOR CUP & Vranovská přehrada & SRPEN & Znojmo & 260 & 1790 & 375 & 1415 & 80 & -50 & 20 & 0 & 121488 & 294977 & 2,2 & 143 & 6339 & 203 & 68 & 73 \\
\hline AMT & AUTHOR 50 BEZDĚZ & Bezděz & KVĚTEN & Česká Lípa & 666 & 1825 & 560 & 1265 & 41 & 120 & 161 & 46 & 95720 & 307323 & 3,2 & 101 & 7446 & 92 & 308 & 535 \\
\hline KPž & KOUTY MTB MARATON ČS & Kouty & SRPEN & Šumperk & 700 & 1570 & 635 & 935 & 60 & 330 & 100 & 0 & 343817 & 100691 & 3,3 & 10 & 571 & 251 & 136 & 537 \\
\hline AMT & AUTHOR PRAŽSKÁ 50 & Praha_Dejvice-Okoř azpě & ZÁŘí & Kladno & 703 & 960 & 170 & 790 & 61 & -60 & 20 & 150 & 16329 & 32211 & 2,1 & 23 & 920 & 30 & 242 & 98 \\
\hline AMT & MALEVIL CUP BY AUTHOR & Jablonné v Podještědí & ČERVEN & Liberec & 865 & 1910 & 510 & 1400 & 21 & 91 & 101 & 51 & 90877 & 256168 & 2,9 & 89 & 6144 & 110 & 309 & 520 \\
\hline KPŽ_t & JESTŘEBÍ HORY ČS & Úpice & KVĚTEN & Náchod & 875 & 1575 & 555 & 1020 & 60 & 190 & 140 & 15 & 120088 & 46191 & 3 & 56 & 2785 & 156 & 158 & 405 \\
\hline KPŽ & KARLOVARSKÝ BIKEMARATON ČS & Karlovy Vary & SRPEN & Karlovy Vary & 875 & 1535 & 465 & 1070 & 40 & 230 & 0 & 0 & 258463 & 77792 & 6 & 150 & 12531 & 128 & 338 & 459 \\
\hline KPŽ & JEŠTĚD TOUR ČS & Liberec & ČERVEN & Liberec & 925 & 1910 & 510 & 1400 & 20 & 150 & 100 & 150 & 90877 & 256168 & 2,9 & 89 & 6144 & 110 & 309 & 520 \\
\hline AMT & AUTHOR 50 ČESKÝ RÁJ & Branžeš - Nová Ves & DUBEN & Mnichovo Hradiště & 1109 & 970 & 455 & 515 & 40 & 130 & 120 & 150 & 16813 & 52621 & 3,1 & 30 & 1619 & 76 & 275 & 430 \\
\hline KPž & ORLÍK TOUR ČS & Orlik & ČERVEN & Přibram & 1125 & 1390 & 535 & 855 & 0 & 120 & 0 & 105 & 46280 & 161063 & 3,2 & 74 & 5106 & 85 & 253 & 652 \\
\hline KPž & VRCHLABÍ ŠPINDL TOUR ČS & Vrchlabí & ČERVENEC & Vrchlabí & 1125 & 1275 & 530 & 745 & 60 & 290 & 160 & 0 & 696875 & 200598 & 4 & 296 & 13275 & 130 & 255 & 193 \\
\hline KPŽ & ŠUMAVSKÝ MTB MARATON ČS & Zadov & ČERVENEC & Vimperk & 1150 & 1160 & 650 & 510 & 140 & 430 & 200 & 0 & 63371 & 212132 & 3,2 & 130 & 4717 & 148 & 266 & 274 \\
\hline AMT & AUTHOR ŠELA MARATHON & Lipník nad Bečvou/Helfštýn & , IIVĚTEN & Lipník nad Bečvou & 1179 & 505 & 310 & 195 & 0 & -20 & 0 & 150 & 3883 & 7661 & 2,2 & 4 & 147 & 311 & 109 & 150 \\
\hline KPž & PLZAŇSKÁ PADESÁTKA ČS & Plzeň & ZÁŔí| & Plzeň & 1300 & 1895 & 560 & 1335 & 0 & 80 & 0 & 150 & 88472 & 168702 & 1,9 & 71 & 5655 & 92 & 297 & 159 \\
\hline KPž & MANITOU ŽELEZNÉ HORY ČS & Chrudim & SRPEN & Chrudim & 1325 & 1355 & 490 & 865 & 60 & 160 & 20 & 30 & 189053 & 77530 & 2 & 67 & 3908 & 133 & 129 & 469 \\
\hline KPŽ & ODESRKÁ MLÝNICE ČS & Klokočůvek u Oder & ZÁŘí & Odry & 1350 & 675 & 430 & 245 & 0 & 160 & 0 & 150 & 8473 & 21735 & 2,5 & 15 & 862 & 336 & 133 & 124 \\
\hline AMT & AUTHOR ZNOVÍN CUP & Šatov & ČERVENEC & Znojmo & 1418 & 1790 & 375 & 1415 & 80 & -50 & 20 & 0 & 121488 & 294977 & 2,2 & 143 & 6339 & 203 & 68 & 73 \\
\hline KPž & VYSOČINA ARÉNA TOUR ČS & Nové Město & ŘÍJEN & Nové Město na Morave & 1450 & 730 & 440 & 290 & 80 & 200 & 40 & 0 & 80771 & 236192 & 2,9 & 66 & 3949 & 166 & 86 & 372 \\
\hline KPŽ & MLADÁ BOLESLAV TOUR ČS & Mladá Boleslav & KVĚTEN & \begin{tabular}{|l|} 
Mladá Boleslav \\
\end{tabular} & 1475 & 1195 & 230 & 965 & 0 & 40 & 0 & 150 & 57470 & 25684 & 2 & 47 & 2059 & 64 & 263 & 225 \\
\hline KPŽ & TRANS BRDY ČS & Lety u Prahy & DUBEN & Černošice & 1600 & 1235 & 480 & 755 & 20 & 80 & 0 & 150 & 79610 & 38640 & 2 & 74 & 3083 & 28 & 215 & 321 \\
\hline KPŽ & PRAHA KARLŠTEJN TOUR ČS & Praha-Chuchle & ČERVENEC & Beroun & 1625 & 1340 & 430 & 910 & 60 & 120 & 160 & 150 & 64921 & 35079 & 2 & 45 & 1680 & 13 & 240 & 297 \\
\hline KPŽ & BIKEMARATON DRÁSAL ČS & Holešov & ČERVEN & Holešov & 1725 & 430 & 205 & 225 & 0 & 80 & 0 & 135 & 799 & 2963 & 3,9 & 3 & 134 & 284 & 81 & 0 \\
\hline KPŽ & VYLTICKÉ CYKLOBRANÍ ČS & Hustopeče & DUBEN & Břeclav & 1800 & 1022 & 303 & 718 & 0 & 80 & 20 & 150 & 98281 & 194760 & 2 & 108 & 5094 & 231 & 59 & 32 \\
\hline KPŽ & ZNOJMO BURČÁK TOUR ČS & Znojmo & ZÁŘ́í & Znojmo & 2100 & 1790 & 375 & 1415 & 80 & 80 & 20 & 0 & 125448 & 308277 & 2,3 & 143 & 6339 & 203 & 68 & 73 \\
\hline AMT & AUTHOR KRÁLŠUMAVY & Klatovy & KVĚTEN & Klatovy & 2150 & 1735 & 660 & 1075 & 81 & 331 & 221 & 31 & 74065 & 227183 & 3,0 & 119 & 4829 & 131 & 336 & 585 \\
\hline AMT & ČT AUTHOR CUP & Josefův Důl & ŘíIEN & Jablonec nad Nisou & 2995 & 1020 & 775 & 245 & 81 & 270 & 0 & 150 & 68830 & 229394 & 3,3 & 137 & 4973 & 108 & 307 & 192 \\
\hline & & & & AMT průměr & 724 & 1520 & 452 & 1068 & 42 & 105 & 76 & 71 & 126723 & 163626 & 3 & 80 & 4959 & 141 & 220 & 361 \\
\hline & & & & AMT SMD & 251 & 334 & 127 & 273 & 22 & 121 & 55 & 63 & 91726 & 100947 & 1 & 44 & 3299 & 68 & 96 & 188 \\
\hline & & & & KPŽ ČS průměr & 1582 & 1208 & 458 & 751 & 44 & 144 & 51 & 88 & 109888 & 143681 & 3 & 91 & 4244 & 157 & 186 & 247 \\
\hline & & & & KPŽ ČS SMD & 452 & 421 & 145 & 394 & 41 & 119 & 74 & 66 & 149244 & 99617 & 1 & 66 & 2915 & 89 & 92 & 176 \\
\hline & & & & AMT + KPŽ ČS průměr & 1264 & 1324 & 455 & 868 & 43 & 130 & 60 & 82 & 116123 & 151068 & 3 & 87 & 4509 & 151 & 199 & 289 \\
\hline & & & & AMT + KPŽ ČS SMD & 567 & 424 & 141 & 389 & 36 & 123 & 70 & 67 & 132996 & 102334 & 1 & 60 & 3139 & 83 & 96 & 192 \\
\hline
\end{tabular}

Zdroj: vlastní

Legenda: $\boldsymbol{P}$. Start - průměrný počet startujicich, $\boldsymbol{B}_{-} \boldsymbol{C P}$ - body celkový potenciál cestovního ruchu ORP, $\boldsymbol{B}_{-} \boldsymbol{P L}$ - body potenciál ploch a linii ORP, $\boldsymbol{B}_{-} \boldsymbol{P A}-$ body př́rodní atraktivity ORP, $\boldsymbol{B} \_\boldsymbol{C H K O / N P}$ - body potenciál ploch Chráněných krajinných oblastí a Národních parků ORP, $\boldsymbol{B} \_$TYP - body Typ krajiny ORP, $\boldsymbol{B} \_P \boldsymbol{P}$ - body prírodní pozoruhodnosti na území ORP, $\boldsymbol{B} \_D D$ -

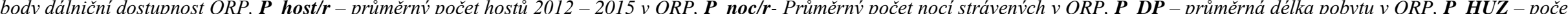
hromadných ubytovacich zařizení v ORP, P PL - průmérný počet lůžek v HUZ v ORP, Km Praha - vzdálenost mista startu od Prahy, Km Brno - vzdálenost mista startu od Brna, Vhodn.Cyklo- vhodnost krajiny pro cykloturistiku 